\title{
The In-Home Environment and Household Health: A Cross-Sectional Study of Informal Urban Settlements in Northern México
}

\author{
Jay P. Graham ${ }^{1 *}$, Verónica Corella-Barud ${ }^{2}$, Raquel Avitia-Diaz ${ }^{3}$, and Patrick Gurian ${ }^{4}$ \\ ${ }^{1}$ Division of Environmental Health Engineering, Department of Environmental Health Sciences, Johns Hopkins Bloomberg \\ School of Public Health, 615 N. Wolfe St., Room E6642, Baltimore, MD 21205, USA \\ ${ }^{2}$ The University of Texas at El Paso, 500 W. University Ave., El Paso, TX 79968, USA \\ ${ }^{3}$ Universidad Autónoma de Ciudad Juárez, Henry Dunant 4016, Zona Pronaf, Cd. Juárez, Chihuahua, México \\ ${ }^{4}$ Department of Civil, Architectural, and Environmental Engineering, Drexel University, Philadelphia, PA 19104, USA \\ *Correspondence to Dr. Jay P. Graham. Email: jgraham@jhsph.edu
}

Received: 26 July 2005 / Accepted: 20 December 2005 / Published: 30 December 2005

\begin{abstract}
People living in poverty make up nearly half of the global population and a large proportion of these individuals inhabit cities, living in informal settlements. However, only limited research on in-home environmental exposures and the associated health effects in these communities is available. This research investigates the home environment in unplanned settlements of a rapidly growing city on the U.S.-México border and its impact on the health of households with children under 12 years of age. A cross-sectional design was used to assess household exposures and health outcomes at the household level. A total of 202 households were selected from two informal settlements in the peri-urban region of Ciudad Juárez, México. The following variables were significantly associated with the report of at least one household member experiencing a health outcome in a two week period. Allergies were positively associated with insecticide use inside the home (adjusted Relative Odds (RO), 2.71; 95\% confidence interval (CI), 1.2-6.3). Respiratory problems were associated with households using a wood burning stove vs. a gas stove (adjusted RO, 5.64; 95\% CI, 1.1-27.9). Diarrhea was negatively associated with presence of a flush toilet in the home (adjusted RO, 0.22; 95\% CI,0.1-0.6). Finally, eye irritations were positively associated with indoor tobacco smoke (adjusted RO, 2.23; 95\% CI, 1.1-4.5). This research highlights exposures associated with poor living conditions in informal settlements and their associations with detrimental effects on health. More efforts should be made to understand the dynamics of poor urban environments including the health effects of exposures linked with poor housing conditions.
\end{abstract}

Keywords: Urbanization, US-Mexico border, housing, children's health, poverty.

\section{Introduction}

In the last two centuries, the percentage of urban residents increased from $5 \%$ to $50 \%$ and current estimates suggest that it will be $66 \%$ by 2030 [1]. In theory, living in urban areas offers the potential for improved health. This is, in part, due to improved access to health care, education and better housing, but also to improved economic conditions [2]. Overall, cities in developing countries account for 50 to 80 percent of their nation's GNP, and per capita income growth has been associated with high levels of urbanization. However, there is wide inter-city and intra-city variability, especially in developing countries, and statistical indicators can be given to support both positive and negative views of the urban environment $[3,4]$.
The growth of cities in developing countries also means the growth of poverty, as poor, often illiterate, and unskilled people leave rural areas to find employment in cities. When urban populations are economically disaggregated, research indicates that the urban poor experience a "double burden" of disease, meaning that they face both the health problems of the "South" (e.g., infectious diseases) and problems of the "North" (e.g., respiratory and circulatory diseases) [5]. In Accra, Ghana and São Paulo, Brazil, researchers found that diseases of the circulatory system (i.e., diseases of the North) make up the main cause of death in the whole population. Moreover, when the cities were divided into zones, according to socio-economic status (SES) indicators, age-adjusted rates of mortality from heart disease were 2.3 times higher for the population in the 
lowest SES zone compared to rates of the highest SES zone. Considerable differences in mortality rates due to respiratory problems were also found [5, 6]. Additionally, studies have shown that child morbidity and mortality rates in poor urban communities can equal or surpass those in rural communities [7, 8]. Graham et al. found that more risk factors and negative health outcomes were associated with unplanned communities compared to government planned communities with subsidized infrastructure, such as drinking water and sewers, even when SES was slightly higher in the unplanned communities. Having adequate housing infrastructure appeared to provide a number of benefits to health and behavior beyond the simple provision of water and sewage infrastructure, including less use of pesticides and safer storage of toxic chemicals [9].

Globally, the United Nations estimates that one billion people live in slums. That number is expected to double by 2030 [10]. Some forty percent of the urban population of South America (115 million people) are poor, living in ciudades jóvenes and favelas (slums) on the periphery of cities and mostly lacking municipal services [11]. According to the United Nations, seventy-one percent of the population of sub-Saharan Africa live in slums, and in Asia, the UN estimates that 554 million people live in slums.

Cities are not as healthy as once thought, especially when health information is disaggregated and informal settlements are taken into consideration [3]. Intra-urban health data are lacking and most frequently come from specific studies rather than systematic data collection performed by the countries or the cities themselves, though efforts are being made to improve this situation $[3,5]$.

Several studies have looked at exposures relevant to the in-home environment, and associated health outcomes (Table 1). Most of these studies, however, focus on specific exposures and health outcomes and provide a more narrow assessment of the in-home environment.

\section{Ciudad Juárez, México}

Migration to urban areas in México has been attributed to industrial growth and accelerated rural emigration due to the "capitalist modernization" of agriculture in the northern portion of the country [12]. Furthermore, with the passage of the North American Free Trade Agreement in 1994, urban growth, especially on the US-México border, has increased $[13,14]$. This growth has overwhelmed municipal authorities and city planners, resulting in the development of several unplanned colonias (neighborhoods) lacking basic municipal services. Though the growth rate has diminished since the economic downturn in recent years, Ciudad Juárez maintains a higher growth rate than most Mexican cities (4.35\%) [15]. Most growth occurs by expansion at the periphery of the city (peri-urbanization) where infrastructure for piped water, sewage services, and in some places electricity is non-existent. According to the Institute of Municipal Research and Planning (Instituto Municipal de Investigación y Paneación), 27,000 homes out of approximately 300,000 homes in Ciudad Juárez are located in high risk zones and nearly
75,000 homes are in poor condition, lacking water and sewage infrastructure and/or are poorly constructed [16]. Additionally, several of the peri-urban communities do not have access to many services (e.g., medical, informational, etc.) that exist in more developed parts of the city. This lack of infrastructure results in polluted environments and more hazardous behaviors that increase the rate of disease and injury for thousands of Juárez residents [15]. Redlinger et al. (2002) found that the proportion of households living in the peri-urban region of Ciudad Juárez and positive for Giardia and Cryptosporidium was high, $82 \%$ and $70 \%$ respectively [17]. According to the $\mathrm{Cd}$. Juárez Fire Department, 222 poisonings and 24 deaths occurred in the 2000-2001 winter season as a result of high carbon monoxide levels in the home, corresponding to an annual death rate of approximately 2/100,000 residents.

This paper addresses the in-home environment and health outcomes associated with living in informal settlements. A case study of peri-urban communities in Ciudad Juárez, a rapidly industrializing city of Northern México, is presented to provide a clearer picture of living conditions and environmental exposures affecting the urban poor. Finally, we discuss current and potential preventive measures that may potentially ameliorate the conditions of the urban poor.

Table 1: In-home exposures and associated health outcomes found in other studies.

\begin{tabular}{ll}
\hline In-home Exposure & Associated Outcome \\
\hline Water supply, sanitation & Infectious Diseases [28] \\
and hygiene facilities & $\begin{array}{l}\text { Diarrhoea [29] } \\
\text { Tuberculosis [30] } \\
\text { Soap }\end{array}$ \\
Crowding & Psychological Distress [32] \\
& Respiratory Problems [33] \\
Passive smoke & Headaches and Acute \\
Carbon monoxide & Intoxications [34] \\
& Neurodevelopment \\
Lead & Abnormalities [35] \\
& Accidental Poisonings [36] \\
Chemicals/Pesticides & Respiratory Problems [37] \\
Damp and moldy housing & Burns, Falls and Other \\
Clutter and poor home & Injuries [38] \\
design & Cardiovascular Disease \\
High variation in indoor & [39] Irritability, Death and \\
Temperatures (Extreme & Lower Health Status [40] \\
cold and hot Temperatures) & Sleep Deprivation and \\
Excessive noise & Stress [41] \\
Nitrogen dioxide & Asthma Symptoms [42] \\
Mouse allergens & Allergies and Asthma [43] \\
Cockroaches & Allergic Sensitization [44] \\
Pets & Allergic Sensitization, and \\
& Asthma [45] \\
\hline
\end{tabular}

\section{Materials and Methods}

Two unplanned colonias (neighborhoods) were randomly selected from two different areas of the city (northwest and south-central region) to be enlisted in the 
study from the total number of settlements in each region. Data were collected from surveys administered during face-to-face interviews and direct observation from 202 households (one hundred and one households in each colonia). The two colonias selected, "Siglo XXI" in the northwest and "6 de Enero", in the southcentral region, were developed without governmental planning and generally lacked municipal water and sanitation services. Study participants in both communities were of low socio-economic status.

\section{Data Collection}

Data collection occurred from December, 2001 to April, 2002. Approval from The University of Texas at El Paso, Institutional Review Board for the protection of human subjects was obtained to perform the study. Two-hundred and two households (with children $<12$ years of age) participated. Data on environmental hazards in and around the home were ascertained through face-to-face interviews with the primary caregiver of the household's children. Interviews were carried out in each respondent's home using a questionnaire containing closed and open-ended questions. The questionnaire was pre-tested in a Juárez neighborhood not participating in the study, and was modified to improve those questions found unclear. The questionnaire included topics such as water for drinking and non-drinking purposes, hygiene and sanitation practices, the use of insecticides and other chemicals in the home, indoor air quality, and health outcomes. A 2-week recall period was used to estimate prevalence of health outcomes.

In addition to the questionnaire, the researchers collected data through direct observation and in-home sampling. Observations were made regarding construction materials, insulation of the home, type of containers used for storing water, presence of animals in and around the home, solid waste management practices and sanitation (i.e., excreta disposal). Painted walls, wood, or metal surfaces along with pottery used for storage of food or water were tested for lead using LeadCheck Swabs ${ }^{\circledR}$ (HybriVet Systems, Inc.). Residual chlorine levels in drinking water were assessed using the N,N-diethylphenylenediamine (DPD) colorimetric method (PermaChem, Hach Company, Loveland, CO). Much of the data collection was planned for the winter so that researchers could take in situ measurements of carbon monoxide as people were heating their homes. Carbon monoxide levels were measured in the kitchen and living room or most commonly used family space of the home using the Bacharach Snifit-50 Carbon Monoxide tester ${ }^{\mathbb{B}}$.

\section{Data analysis}

Statistical analyses were carried out using STATA 8 statistical software ${ }^{\circledR}$. Six health outcomes and multiple potential exposures were investigated (Table 2). Differences in housing and household characteristics for the two communities studied, including water and sanitation infrastructure, were assessed using simple descriptive statistics.

Table 2: Health outcomes and independent variables considered potential risk factors.

Health Outcome Independent Variables

\begin{tabular}{ll}
\hline Allergies & Smoking indoors, size of \\
& household, household \\
& income, type of heating \\
& system, use of insecticide \\
& in the home, animals kept \\
& inside the home, and \\
percentage of household & from Juárez
\end{tabular}

Respiratory problems
(i.e., asthma)

Diarrhoea

Eye irritation

Sore throat

Skin irritation

For each outcome, univariate and multivariate logistic regression analyses were conducted to estimate the magnitude of associations with household exposures. Health outcomes were defined as "at least one household member experiencing the health outcome in the last two

Smoking indoors, size of household, household income, type of heating system, use of insecticide in the home, animals kept inside the home, and percentage of household from Juárez

Drinking water source, type of storage container, type of sanitation system, household size, household income, animals kept inside the home, and chlorine residual in drinking water

Smoking indoors, size of household, household income, type of heating system, use of insecticide in the home, animals kept inside the home, and percentage of household from Juárez

Smoking indoors, size of household, household income, type of heating system, use of insecticide in the home, animals kept inside the home, and percentage of household from Juárez

Smoking indoors, size of household, household income, type of heating system, use of insecticide in the home, animals kept inside the home, and percentage of household from Juárez 
weeks." The analysis was conducted at the household level, because the exposure analysis was conducted on this level, and because analysis of individual-level outcomes is complicated by the fact that health outcomes among family members are not statistically independent.

The multivariate regression analyses included an adjustment for the mean number of residents per home, since the likelihood of at least one member having the health outcome increases when more people live in the home. Other socio-demographic variables included household income, and the percentage of the household from Juárez. It was hypothesized that households that had more recently immigrated to Juárez might have more health problems, due to the changes in the physical and social environment.

\section{Results}

Table 3 provides a summary of household characteristics. The colonia Siglo XXI experienced a slightly lower standard of living, with, on average, more individuals per household and a lower mean household income. Smoking tobacco was also more prevalent in Siglo XXI. Both communities, on average, were spending approximately $6 \%$ of their earnings on utilities, (water and electricity). Interestingly, there were several who connected to water illegally, while others receiving water from delivery trucks received very little water but generally paid more. At the time of the study, there was a shortage in the labor supply and the maquiladora (i.e., assembly plant) industry was hiring on a continual basis. However, with the economic downturn of the past few years, beginning in 1999, the demand for labor has decreased. Despite the reduced demand for labor, rapid in-migration to Ciudad Juárez has continued.

Table 3: Household characteristics for unplanned colonias

\begin{tabular}{|c|c|c|c|}
\hline $\begin{array}{l}\text { Household } \\
\text { Characteristics }\end{array}$ & $\begin{array}{l}\text { Siglo } X X I \\
(n=101)\end{array}$ & $\begin{array}{l}6 \text { D e Enero } \\
(n=101)\end{array}$ & $\begin{array}{c}\text { Total } \\
(n=202)\end{array}$ \\
\hline $\begin{array}{l}\text { Mean \# of Residents } \\
\text { per Home }\end{array}$ & 5.53 & 5.25 & 5.39 \\
\hline $\begin{array}{l}\text { Mean \# of Children } \\
(<5 \mathrm{yrs} \text { of age })\end{array}$ & 1.10 & 1.04 & 1.07 \\
\hline $\begin{array}{l}\text { Mean \# of Children } \\
\text { (ages 6-12) }\end{array}$ & 1.19 & 1.14 & 1.16 \\
\hline $\begin{array}{l}\text { Percentage of } \\
\text { household born in } \mathrm{Cd} \text {. } \\
\text { Jaurez }\end{array}$ & $48.8 \%$ & $47.9 \%$ & $48.3 \%$ \\
\hline $\begin{array}{l}\text { Persentage of } \\
\text { Household with } \\
\text { telephone }\end{array}$ & $45.5 \%$ & $72.3 \%$ & $58.9 \%$ \\
\hline $\begin{array}{l}\text { Percentage of } \\
\text { household exposed to } \\
\text { indoor tobacco smoke }\end{array}$ & $37.6 \%$ & $22.8 \%$ & $30.2 \%$ \\
\hline \multicolumn{4}{|c|}{ Household Financial Characteristics } \\
\hline $\begin{array}{l}\text { Mean in household } \\
\text { income (US\$/month) }\end{array}$ & 511.60 & 580.80 & 546.00 \\
\hline $\begin{array}{l}\text { Mean income per } \\
\text { household member } \\
\text { (US\$/month) }\end{array}$ & 92.51 & 110.63 & 101.30 \\
\hline $\begin{array}{l}\text { Mean utility costs } \\
\text { (US\$/month) }\end{array}$ & 32.42 & 33.67 & 33.04 \\
\hline
\end{tabular}

There was considerable variation in housing conditions, with the majority of houses being constructed of concrete blocks and concrete floors. Siglo XXI, however, experienced poorer building quality, with $33.7 \%$ of the houses having pallet or cardboard walls, $34.6 \%$ exposed electrical wires, and $28.7 \%$ with dirt floors. While more households in 6 de Enero used insecticide inside the home, methyl-parathion, an extremely toxic pesticide, was more commonly used in Siglo XXI, $10 \%$, versus $5 \%$ in 6 de Enero.

The source or drinking water varied substantially (Table 4). Pit latrines were more common in Siglo XXI than in 6 de Enero, $37.6 \%$ and $15.8 \%$ respectively. Table 4 presents several characteristics of environmental conditions and their prevalence in each community.

Table 4: Housing characteristics for unplanned communities

\begin{tabular}{|c|c|c|c|}
\hline $\begin{array}{l}\text { Housing } \\
\text { Characteristics (\%) }\end{array}$ & $\begin{array}{l}\text { Siglo XXI } \\
(n=101)\end{array}$ & $\begin{array}{c}6 \text { De Enero } \\
(n=101)\end{array}$ & $\begin{array}{c}\text { Total } \\
(n=202)\end{array}$ \\
\hline $\begin{array}{l}\text { Pallet or cardboard } \\
\text { construction }\end{array}$ & $33.7 \%$ & $4.9 \%$ & $19.3 \%$ \\
\hline $\begin{array}{l}\text { Exposed electric wires } \\
\text { in home }\end{array}$ & $34.6 \%$ & $26.7 \%$ & $30.7 \%$ \\
\hline Dirt floors & $28.7 \%$ & $4.0 \%$ & $16.3 \%$ \\
\hline Debris present in yard & $72.3 \%$ & $12.9 \%$ & $42.6 \%$ \\
\hline Tires present in yard & $42.6 \%$ & $2.0 \%$ & $22.3 \%$ \\
\hline $\begin{array}{l}\text { Animals kept inside } \\
\text { home }\end{array}$ & $64.3 \%$ & $11.9 \%$ & $38.1 \%$ \\
\hline $\begin{array}{l}\text { Insecticide used inside } \\
\text { home }\end{array}$ & $64.4 \%$ & $66.3 \%$ & $65.3 \%$ \\
\hline $\begin{array}{l}\text { Serious accident in last } \\
2 \text { months* }\end{array}$ & $17 \%$ & $5.9 \%$ & $11.4 \%$ \\
\hline
\end{tabular}

\section{Home Heating Method}

$\begin{array}{lccc}\text { Gas } & 26.7 & 33.7 & 30.2 \\ \text { Electric } & 10.9 & 23.8 & 17.3 \\ \text { Wood stove } & 42.6 & 16.8 & 29.7 \\ \text { Cooking stove } & 6.9 & 3.0 & 5.0 \\ \text { Do not heat home } & 11.9 & 18.8 & 15.3 \\ \text { Other } & 1.0 & 4.0 & 2.5\end{array}$

Water connection in-

$\begin{array}{lccc}\text { Water connection in- } & 1.0 \% & 33.7 \% & 16.8 \% \\ \text { home } & 37.6 \% & 0 \% & 18.8 \% \\ \text { Pipa (truck) } & 14.8 \% & 43.5 \% & 29.2 \% \\ \text { Water connection } & 39.6 \% & 20.8 \% & 30.2 \% \\ \text { outside home } & 7.0 \% & 2.0 \% & 4.9 \% \\ \text { Purchase drinking water } & \end{array}$

Type of Sewage Disposal (\%)

In-home connection to

\begin{tabular}{|c|c|c|c|}
\hline $\begin{array}{l}\text { In-home connection to } \\
\text { sewage system }\end{array}$ & $3.0 \%$ & $34.6 \%$ & $18.8 \%$ \\
\hline Latrine & $37.6 \%$ & $15.8 \%$ & $26.7 \%$ \\
\hline $\begin{array}{l}\text { n-home connection to } \\
\text { atrine }\end{array}$ & $12.9 \%$ & $41.6 \%$ & $27.2 \%$ \\
\hline $\begin{array}{l}\text { n-home connection to } \\
\text { eptic tank }\end{array}$ & $44.5 \%$ & $7.0 \%$ & $25.7 \%$ \\
\hline ther & $2.0 \%$ & $1.0 \%$ & $1.5 \%$ \\
\hline
\end{tabular}

*In or around the home 
Many of the individuals migrating to $\mathrm{Cd}$. Juárez come from southern México, which has a much milder winter climate. Such migrants are not accustomed to heating their homes in the winter. Though cold temperatures occurred frequently during the five month study period $\left(53\right.$ days $\left.\leq 32^{\circ} \mathrm{F}\right)$ in the city during the winter and early spring, a large percentage of the individuals in our study $(15 \%)$ reported not heating their homes. Concentrations of $\mathrm{CO}$ greater than $25 \mathrm{ppm}$ are considered unhealthy, assuming the exposure lasts one hour or more. Our study results indicate very high levels of carbon monoxide in the homes of both communities. Measurements of $\mathrm{CO}$ in homes reporting to not heat their home were high - 11 of the 31 homes reporting to not heat their home had CO levels above $25 \mathrm{ppm}$. No significant difference was found between $\mathrm{CO}$ levels in households heating their homes with gas stoves vs. homes heated with wood burning stoves. Additionally, $\mathrm{CO}$ levels were not significantly higher in homes exposed to passive tobacco smoke. Figure 1 provides a box plot of the CO levels in study homes of the communities Siglo XXI and 6 de Enero.

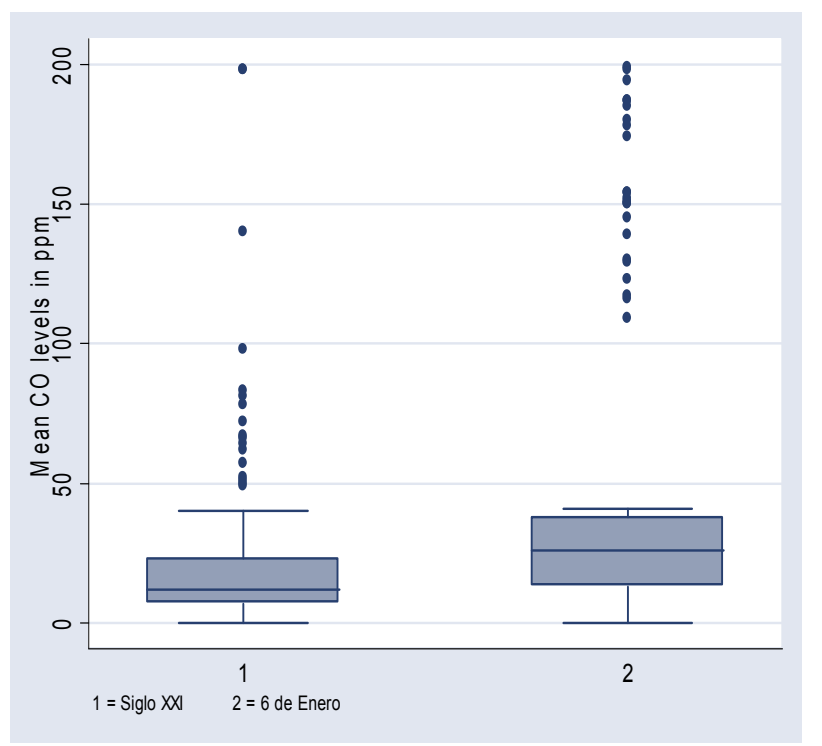

Figure 1: Indoor $\mathrm{CO}$ levels in informal settlement homes

Differences in the prevalence of reported health outcomes between the two communities were compared (Table 5). A difference in the number of health outcomes between the two communities indicates that there may be systematic differences in the two communities and thus the community should be placed into the multiple logistic regression models to control for its effect. Based on the results, an indicator for community was added to regression models, in Table 6, for the health outcomes "sore throat" and "skin irritation", in order to control for the effect of community.

Table 6 presents the crude and adjusted relative odds of various health outcomes for each of the household hazards assessed in the study. The adjusted relative odds models include all of the variables listed in Table 1.
Table 5: Percentage of households with at least one household member experiencing health outcome

\begin{tabular}{lccc}
\hline $\begin{array}{l}\text { Health Outcome } \\
\text { (2-Week Prevalence) }\end{array}$ & $\begin{array}{c}\text { Siglo XXI } \\
(n=101)\end{array}$ & $\begin{array}{c}\text { 6 De Enero } \\
(n=101)\end{array}$ & PValue* \\
\hline Allergies & $22.8 \%$ & $21.8 \%$ & 0.867 \\
Respiratory Problems & $16.8 \%$ & $16.8 \%$ & 1.000 \\
Diarrhoea & $18.8 \%$ & $13.9 \%$ & 0.341 \\
Eye Irritation & $31.7 \%$ & $35.6 \%$ & 0.551 \\
Sore Throat & $51.5 \%$ & $32.7 \%$ & 0.007 \\
$\begin{array}{l}\text { Skin Irritation } \\
\text { (eg Rash) }\end{array}$ & $32.7 \%$ & $17.8 \%$ & 0.015 \\
\hline
\end{tabular}

*P-value from Chi-square test

Allergies were associated with insecticide use inside the home (adjusted Relative Odds (RO), 2.71; 95\% confidence interval (CI), 1.2-6.3). Respiratory problems (e.g., asthma) were associated with households using a wood burning stove vs. a gas stove (adjusted RO, 5.64; 95\% CI, 1.1-27.9).

Lower reported incidents of diarrhea, defined as 3 loose stools in a 24-hour period, were associated with having a flush toilet in the home (adjusted RO, 0.22; $95 \% \mathrm{CI}, 0.1-0.6)$ and with obtaining drinking water from a connection in the home rather than from a delivery truck (adjusted RO, 0.16; 95\% CI, 0.1-1.2). Finally, eye irritations were associated with indoor tobacco smoke (adjusted RO, 2.23; 95\% CI, 1.1-4.5).

\section{Discussion}

This is one of the first studies to assess multiple exposures at the household level in informal settlements. The study highlights a number of in-home environmental hazards which may potentially impact the health of households living in similar environments. The environmental health conditions in these communities are rarely studied and narrowly focused studies, describing one exposure, are often inadequate in describing the general environmental health conditions present in these homes. We believe this study provides an important background for additional research into the effects of urbanization and the development of informal communities.

Housing characteristics varied substantially between the two communities in our study, indicating the heterogeneity of conditions in informal settlements. Improvements to homes, such as the building of concrete walls, were noted in both communities, suggesting that households planned to make the home a more permanent dwelling. The differences in the two communities were not well understood though the community " 6 de Enero" had been in existence a longer period of time and was more closely situated near areas connected to the city's water and sewage infrastructure.

Studies have shown that high concentrations of $\mathrm{CO}$ in indoor air are associated with higher daily mortality rates, though many mild exposures go undetected; one study suggests that nearly one-third of all $\mathrm{CO}$ poisoning cases go undiagnosed [18]. Fetuses are especially 
Table 6: Crude and adjusted relative odds of selected health outcomes.

\begin{tabular}{|c|c|c|c|c|c|c|}
\hline \multirow{2}{*}{ Health Outcome (2-Week Prevalence) } & \multicolumn{3}{|c|}{ Crude } & \multicolumn{3}{|c|}{ Adjusted* } \\
\hline & $R O$ & $95 \% C I$ & P Value & $R O$ & $95 \% C I$ & $P$ Value \\
\hline \multicolumn{7}{|c|}{ Allergies } \\
\hline Insecticide used inside home & 2.54 & $(1.1-5.6)$ & 0.02 & 2.71 & $(1.2-6.3)$ & 0.02 \\
\hline Smoking inside home & 0.50 & $(0.2-1.1)$ & 0.10 & 0.57 & $(0.2-1.4)$ & 0.21 \\
\hline Wood burning stove (vs. gas stove) & 0.31 & $(0.1-2.7)$ & 0.29 & 0.31 & $(0.1-3.0)$ & 0.32 \\
\hline Animal kept inside home & 0.77 & $(0.4-1.5)$ & 0.45 & 0.90 & $(0.4-1.9)$ & 0.80 \\
\hline \multicolumn{7}{|c|}{ Respiratory Problems (e.g., asthma) } \\
\hline Wood burning stove (vs. gas stove) & 4.42 & $(1.0-9.2)$ & 0.05 & 5.64 & $(1.1-7.9)$ & 0.03 \\
\hline Insecticide used inside home & 0.71 & $(0.3-1.5)$ & 0.38 & 1.00 & $(0.4-2.3)$ & 0.22 \\
\hline Smoking inside home & 0.80 & $(0.3-1.8)$ & 0.60 & 0.55 & $(0.2-1.4)$ & 0.98 \\
\hline Animal kept inside home & 0.74 & $(0.3-1.6)$ & 0.45 & 0.58 & $(0.2-1.4)$ & 0.22 \\
\hline \multicolumn{7}{|c|}{ Diarrhoea } \\
\hline Flush toilet in home (vs. pit latrine) & 0.22 & $(0.1-0.5)$ & $<0.001$ & 0.22 & $(0.1-0.6)$ & 0.002 \\
\hline $\begin{array}{l}\text { Water connection inside home (vs. delivery by water } \\
\text { truck) }\end{array}$ & 0.27 & $(0.1-1.1)$ & 0.06 & 0.16 & $(0.1-1.2)$ & 0.08 \\
\hline Purchase drinking water (vs. delivery by water truck) & 0.42 & $(0.1-1.2)$ & 0.10 & 0.47 & $(0.1-2.0)$ & 0.30 \\
\hline $\begin{array}{l}\text { Water connection outside home (vs. delivery by water } \\
\text { truck) }\end{array}$ & 0.50 & $(0.2-1.4)$ & 0.18 & 0.42 & $(0.1-1.7)$ & 0.23 \\
\hline Water storage in 55 -gallon drums & 1.58 & $(0.7-3.4)$ & 0.23 & 0.79 & $(0.3-2.4)$ & 0.68 \\
\hline Purify water (e.g., boiling) & 1.03 & $(0.5-2.3)$ & 0.93 & 1.23 & $(0.4-3.4)$ & 0.69 \\
\hline Level of chlorine in drinking water & 0.93 & $(0.5-1.9)$ & 0.85 & 1.04 & $(0.4-2.7)$ & 0.92 \\
\hline Animal kept inside home & 1.44 & $(0.7-3.0)$ & 0.34 & 0.59 & $(0.2-1.7)$ & 0.32 \\
\hline \multicolumn{7}{|c|}{ Eye Irritation } \\
\hline Smoking inside home & 1.75 & $(0.9-3.3)$ & 0.08 & 2.23 & $(1.1-4.5)$ & 0.03 \\
\hline Insecticide used inside home & 0.71 & $(0.4-1.3)$ & 0.28 & 0.59 & $(0.3-1.1)$ & 0.12 \\
\hline Wood burning stove (vs. gas stove) & 1.03 & $(0.3-4.0)$ & 0.97 & 0.54 & $(0.1-2.3)$ & 0.41 \\
\hline Animal kept inside home & 1.11 & $(0.6-2.0)$ & 0.74 & 1.10 & $(0.6-2.1)$ & 0.76 \\
\hline \multicolumn{7}{|c|}{ Sore Throat } \\
\hline Animal kept inside home & 2.10 & $(1.2-3.7)$ & 0.01 & 1.56 & $(0.8-3.2)$ & 0.23 \\
\hline Insecticide used inside home & 0.67 & $(0.4-1.2)$ & 0.17 & 0.78 & $(0.4-1.5)$ & 0.44 \\
\hline Smoking inside home & 0.85 & $(0.5-1.6)$ & 0.61 & 0.66 & $(0.3-1.3)$ & 0.25 \\
\hline Wood burning stove (vs. gas stove) & 2.86 & $(0.7-1.2)$ & 0.13 & 2.74 & $(0.6-2.1)$ & 0.19 \\
\hline \multicolumn{7}{|c|}{ Skin Irritation (e.g., rash) } \\
\hline Insecticide used inside home & 1.22 & $(0.6-2.4)$ & 0.57 & 1.24 & $(0.6-2.7)$ & 0.58 \\
\hline Smoking inside home & 1.73 & $(0.9-3.4)$ & 0.11 & 1.26 & $(0.6-2.7)$ & 0.55 \\
\hline Wood burning stove (vs. gas stove) & 1.72 & $(0.4-6.9)$ & 0.44 & 1.61 & $(0.4-1.8)$ & 0.53 \\
\hline Animal kept inside home & 1.47 & $(0.8-2.8)$ & 0.24 & 0.82 & $(0.4-3.7)$ & 0.88 \\
\hline
\end{tabular}

${ }^{*}$ The model for the adjusted ROs and corresponding CIs and p-values are calculated using variables listed in Table 2. 
sensitive to $\mathrm{CO}$ exposures since fetal hemoglobin has a higher affinity than adult hemoglobin for CO. Households in our study area appeared to be aware of potential problems associated with $\mathrm{CO}$ based on the large percentage $(15 \%)$ that did not heat their homes, partly for fear of $\mathrm{CO}$ intoxication and partly because of the cost of heating. There was no statistically significant difference in the levels of carbon monoxide between homes using gas heating sources and homes relying on wood burning stoves, although Gurian et al. 2005 found that risks for acute intoxication were higher for gas stoves. As urbanization continues, there is the potential that more households will gain access to cleaner fuels, such as propane and methane, and better constructed homes (less ventilated). Though this is generally a positive change, it could result in an increase in carbon monoxide poisonings if the heating and cooking systems are not vented properly.

Respiratory infections continue to be the leading cause of child mortality globally, and indoor air pollution associated with burning biomass fuels is a significant contributor (between 2-3 billion people still rely on these fuels for cooking and heating) [19]. In our study, respiratory problems were associated with households using a wood burning stove vs. a gas stove (adjusted RO, 5.64; 95\% CI, 1.1-27.9) and similar results have been shown in other studies [20]. Improving access to cleanburning, vented gas heating or electric heating should be an important health priority.

Though allergies were associated with insecticide use inside the home, it is difficult to determine whether it is the presence of insects in the home or the use of insecticides that is associated with allergies. From prior research, it would appear that the presence of insects is the likely cause of the association [44].

The World Health Organization estimates that by 2030 , tobacco will be responsible for ten million deaths per year and that $70 \%$ of the deaths will occur in developing countries. In our study, a large percentage of the households were exposed to environmental tobacco smoke, though "eye irritations" was the only health outcome to show a statistically significant association. This study did not differentiate between direct exposures to smokers and indirect exposures to household members through secondhand smoke.

Many households lacked access to a piped water supply and several had water delivered by trucks into 55gallon drums on their property. Households having water delivered used substantially less water but paid up to eight times more than households connected to the public distribution system. Poor sanitation was also widespread, with approximately one-quarter of the households using a pit latrine. This situation is common for millions of households in informal settlements and there is a growing concern that urbanization will increase the number of people lacking a safe water supply and adequate sanitation [7].

Several limitations exist for this study. Due to the cross-sectional design, associations observed in this study may not be causal, even in the absence of bias. Much of the complexity related to the changing environment (e.g., migration, industrialization, inequalities, etc.) is not captured in this study and macrolevel factors such as political and economic variables and community factors are not included. Third, the study did not allow for comparisons at the individual level which limits associations to households.

More research needs to be done on urban health to determine the fundamental characteristics of the urban physical and social environment and what interventions could improve the health of urban populations [21]. Future research could benefit from intercity comparisons within countries and studies of the urban environment between countries [22]. Additionally, there is a need for more useful, disaggregated, statistics for cities that clearly document any disparities in exposure and health status among the many widely differing subpopulations within a city. Finally, there is a need for effective partnering between different sectors (e.g., local, regional, national and international governing bodies and NGOs, social planners, builders, public health officials, urban planners, economists and the private sector). In fact, most of the articles published on the subject of urbanization and health argue for a more integrated approach to solving urban problems and emphasize the need for more collaboration [2, 3, 21, 23-25].

Though it is essential to improve equity and economic factors, targeting exposures has been shown to be effective, especially when directed towards specific conditions and contexts, and particular settings [26, 27]. Waiting for improved city-wide economic changes when acute exposures, such as high CO levels in the case of Cd. Juárez, plague a community would be nonsensical. As an example of targeted programs, communities in $\mathrm{Cd}$. Juárez have participated in Agua Para Beber, a program run by NGOs that trains community health workers to train households in their respective communities on appropriate ways to treat and store their drinking water. The program has reduced diarrheal rates significantly in these communities [26]. Similar studies related to asthma have shown that individualized, home-based interventions can decrease exposures resulting in reduced morbidity [27].

Finally, these findings contribute to the literature documenting environmental exposures in some of the most resource-poor settings. Though further investigation of these in-home exposures is critical to our understanding of the in-home environment in informal settlements, the authors recommend that immediate action be taken to ameliorate the acute exposures.

Acknowledgements: This work was supported by a grant from the Southwest Center for Environmental Research and Policy. Very special thanks go to the students: Daniel Antonio Márquez Olivas, Ángel Gabriel Díaz Sanchez, Carlos David Garcia Muñoz, Liliana Meraz Prieto, Dora Alicia Robles Hernández, Claudia Azucena Jimenez de Estrada, and Ramiro Silva Tena who were instrumental for the completion of this study. We also thank Alberto Barud-Zubillga at The University of Texas at El Paso for his GIS work the community members for their participation in the study. 


\section{References}

1. McMichael A. J.: The urban environment and health in a world of increasing globalization: issues for developing countries. Bull. World Health Organ. 2000, 78, 1117-1126.

2. Lawrence R. J.: Urban health: an ecological perspective. Rev. Environ. Health, 1999, 14, 1-10.

3. Moore M.; Gould P.; Keary B. S.: Global urbanization and impact on health. Int. J. Hyg. Environ. Health, 2003, 206, 269-278.

4. Carty W. P.: Towards an urban world. Earthwatch 1991, 43, 2-4.

5. Stephens C.: The urban environment, poverty and health in developing countries. Health Policy Plan., 1995, 10, 109-121.

6. Stephens C.; Akerman M.; Avle S.; Maia P. B.; Campanario P.; Doe B.; Tetteh D.: Urban equity and urban health: using existing data to understand inequalities in health and environment in Accra, Ghana and Sao Paulo, Brazil. Environ. Urban. 1997, 9, 181-202.

7. Bartlett S. N.: Water, sanitation and urban children: the need to go beyond "improved" provision. Environ. Urba,. 2003, 15, 57-70.

8. Crompton D. W.; Savioli L.: Intestinal parasitic infections and urbanization. Bull. World Health Organ. 1993, 71, 1-7.

9. Graham J.; Gurian P.; Corella-Barud V.; AvitiaDiaz R.: Peri-urbanization and in-home environmental health risks: the side effects of planned and unplanned growth. Int. J. Hyg. Environ. Health, 2004, 207, 447-454.

10. UN-HABITAT: The challenge of slums: Global report on human settlements. United Nations Human Settlements Program, 2003.

11. Joyce S.: Growing pains in South America. Environ. Health Perspect., 1997, 105, 794-799.

12. Castells M.: Squatters and the State in Latin America. In: The urbanization of the third world. Gugler J. (ed.). Oxford University Press: New York 1988; pp. 338-366.

13. Homedes N.; Ugalde A.: Globalization and health at the United States-Mexico Border. Amer. J. Pub. Health 2003, 93, 2016-2022.

14. United States-Mexico Border Health Commission: Annual Report. El Paso, Texas: United StatesMexico Border Health Commission. 2001.

15. Instituto Nacional de Estadística Geografía e Informática (INEGI). Estadisticas del Sector Salud y Seguridad Social, Cuaderno No. 16., Mexico, D. $F$., 2000.

16. Instituto Municipal de Investigación y Planeación (IMIP) El Plan de Desarrollo: Instituto Municipal de Investigacion y Planeacion, $\mathbf{2 0 0 0 .}$

17. Redlinger T.; Corella-Barud V.; Graham J.; Galindo A.; Avitia R.; Cardenas V.: Hyperendemic Cryptosporidium and Giardia in households lacking municipal sewer and water on the United StatesMexico border. Amer. J. Trop. Med. Hyg., 2002, 66, 794-798.
18. Varon J.; Marik P.; Fromm R.; Gueler A.: Carbon monoxide poisoning: a review for clinicians. $J$. Emerg. Med., 1999, 17, 87-93.

19. Bruce N.; Padilla P. R. A.: Indoor air pollution in developing countries: a major environmental and public health challenge. Bull. World Health Organ. 2000, 78, 1078-1092.

20. Belanger K.; Beckett W.; Triche E.; Bracken M. B.; Holford T.; Ren P.; McSharry J. E.; Gold D. R.; Platts-Mills T. A.; Leaderer B. P.: Symptoms of wheeze and persistent cough in the first year of life: associations with indoor allergens, air contaminants, and maternal history of asthma. Amer. J. Epi., 2003, 158, 195-202.

21. Vlahov D.; Galea S.: Urban health: a new discipline. Lancet, 2003, 362, 1091-1092.

22. Vlahov D.; Galea S.: Urbanization, Urbanicity, and Health. Journal of Urban Health: Bull. New York Acad. Med., 2002, 79, S1-S12.

23. Krieger J.; Higgins D. L.: Housing and health: Time again for public health action. Amer. J. Pub. Health 2002, $92,758-768$.

24. Mutatkar R. K.: Public Health Problems of Urbanization. Soc. Sci. Med. 1995, 41, 977-981.

25. Gracey M.: Child health implications of worldwide urbanization. Rev. Environ. Health 2003, 18, 51-63.

26. Vera B.; Bessenecker C.: "Agua Para Beber" Provision of Safe Drinking Water for the Improvement of Drinking Water Quality of LowIncome Communities on the US-Mexico Border. El Paso: The University of Texas at El Paso - Center for Environmental Resource Management, 1995.

27. Morgan W. J.; Crain E. F.; Gruchalla R. S.; O'Connor G. T.; Kattan M.; Evans R.; Stout J.; Malindzak G.; Ernestine S.; Plaut M.; Walter M.; Vaughn B.; Mitchell H.: Results of a Home-Based Environmental Intervention among urban children with asthma. N. Engl. J. Med., 2004, 351, 10681080.

28. Esrey S. A.: Water, waste, and well-being: A multicountry study. Amer. J. Epi., 1996, 143, 608623.

29. Curtis V.; Cairncross S.: Effect of washing hands with soap on diarrhoea risk in the community: a systematic review. Lancet Infect. Dis.. 2003, 3, 275281.

30. Gustafson P.; Gomes V. F.; Vieira C. S.; Rabna P.; Seng R.; Johansson P.; Sandstrom A.; Norberg R.; Lisse I.; Samb B.; Aaby P.; Naucler A.: Tuberculosis in Bissau: incidence and risk factors in an urban community in sub-Saharan Africa. Int. J. Epi., 2004, 33, 163-72.

31. Fonseca W.; Kirkwood B. R.; Victora C. G.; Fuchs S. R.; Flores J. A.; Misago C.: Risk factors for childhood pneumonia among the urban poor in Fortaleza, Brazil: a case-control study. Bull. World Health Organ., 1996, 74, 199-208.

32. Harpham T.: Urbanization and mental health in developing countries: a research role for social scientists, public health professionals and social psychiatrists. Soc. Sci. Med., 1994, 39, 233-245. 
33. Weitzman M.; Gortmaker S.; Walker D. K.; Sobol A.: Maternal smoking and childhood asthma. Pediatrics 1997, 85, 505-511.

34. Ernst A.; Zibrak J.: Carbon Monoxide Poisoning. $N$. Engl. J. Med. 1998, 339, 1603-1608.

35. Tong S.; von Schirnding Y.; Prapamontol T.: Environmental lead exposure: a public health problem of global dimensions. Bull. World Health Organ., 2000, 78, 1068-1077.

36. Andiran N.; Sarikayalar F.: Pattern of acute poisonings in childhood in Ankara: what has changed in twenty years? Turk. J. Ped., 2004, 46, 147-152.

37. Platt S. D.; Martin C. J.; Hunt S. M.; Lewis C. W.: Damp housing, mould growth, and symptomatic health state. Brit. Med. J., 1989, 298, 1673-1678.

38. Bartlett S. N.: The problem of children's injuries in low-income countries: a review. Health Pol. Plan. 2002, 17, 1-13.

39. Collins K. J.: Low indoor temperatures and morbidity in the elderly. Age Aging., 1986, 15, 212220.

40. Evans J.; Hyndman S.; Stewart-Brown S.; Smith D.; Petersen S.: An epidemiological study of the relative importance of damp housing in relation to adult health. J. Epi. Comm. Health, 2000, 54, 677-686.
41. Van Cauter E.; Spiegel K.: Sleep as a mediator of the relationship between socioeconomic status and health: a hypothesis. Ann NY Acad Sci 1999, 896, 918-924.

42. Pilotto L. S.; Nitschke M.; Smith B. J.; Pisaniello D.; Ruffin R. E.; McElroy H. J.; Martin J.; Hiller J. E.: Randomized controlled trial of unflued gas heater replacement on respiratory health of asthmatic schoolchildren. Int. J. Epi., 2004, 33, 208214.

43. Phipatanakul W.; Cronin B.; Wood R. A.; Eggleston P. A.; Shih M. C.; Song L.; Tachdjian R.; Oettgen H. C.: Effect of environmental intervention on mouse allergen levels in homes of inner-city Boston children with asthma. Ann. Allergy Asthma Immunol., 2004, 92, 420-425.

44. Huss K.; Adkinson N. F.; Eggleston P. A.; Dawson C.; Van Natta M. L.; Hamilton R. G.: House dust mite and cockroach exposure are strong risk factors for positive allergy skin test responses in the Childhood Asthma Management Program. J. Allergy Clin. Immunol. 2001, 107, 48-54.

45. Bacharier L. B.; Strunk R. C.; Pets and Childhood Asthma - How Should the Pediatrician Respond to New Information That Pets May Prevent Asthma? Pediatrics 2003, 112, 974-976. 